\title{
A novel role of cellular interactions in vascular calcification
}

\author{
Adham Sameer A. Bardeesi ${ }^{1 \dagger}$, Jingwei Gao ${ }^{2,3 \dagger}$, Kun Zhang ${ }^{2,3 \dagger}$, Suntian Yu ${ }^{1}$, Mengchao Wei ${ }^{1}$, Pinming Liu ${ }^{2,3}$ \\ and Hui Huang ${ }^{2,3^{*}}$
}

\begin{abstract}
A series of clinical trials have confirmed the correlation between vascular calcification (VC) and cardiovascular events and mortality. However, current treatments have little effects on the regression of VC. Potent and illustrative mechanisms have been proven to exist in both bone metabolism and VC, indicating that these two processes share similarities in onset and progression. Multiple osteoblast-like cells and signaling pathways are involved in the process of VC. In this review, we summarized the roles of different osteoblast-like cells and we emphasized on how they communicated and interacted with each other using different signaling pathways. Further studies are needed to uncover the underlying mechanisms and to provide novel therapies for VC.
\end{abstract}

Keywords: Vascular calcification, Osteoblast-like cells, Autophagy, Signaling pathways

\section{Background}

Vascular calcification (VC) is a pathological accumulation of calcium phosphate crystal deposits in the medial and intimal layers of the vessel wall, which complicates the course of chronic kidney disease (CKD), diabetes and atherosclerosis [1]. Patients with VC exhibit an increased risk of cardiovascular events, and no reliable treatments have been found to reverse it yet. Far from a passive process, VC is widely accepted as an active and regulatory process, which shares many similarities with the process of bone formation. Recent clinical data also indicate a close relationship between osteoporosis and $\mathrm{VC}$, suggesting a crosstalk between bones and vascular systems [2]. There are a variety of osteoblast-like cells and mediators involved in this process, termed as "bone-vascular axis" $[2,3]$. However, the underlying molecular mechanisms are largely unknown.

\footnotetext{
*Correspondence: huangh8@mail.sysu.edu.cn

${ }^{\dagger}$ Adham Sameer A. Bardeesi, Jingwei Gao and Kun Zhang contributed equally to this review article

${ }^{2}$ Guangdong Provincial Key Laboratory of Malignant Tumor Epigenetics and Gene Regulation, Department of Cardiology, Sun Yat-sen Memorial Hospital, Sun Yat-sen University, 107 West Yanjiang Road, Guangzhou 510120, China

Full list of author information is available at the end of the article
}

It's widely accepted that vascular smooth muscle cells (VSMCs) have several forms of phenotypes, including contractile, osteoblastic, synthetic phenotypes, which can transfer from one to another in specific conditions. Phenotypic change of VSMCs from contractile to osteoblastic form is considered to be a possible mechanism contributing to the bone-vascular axis [4]. When exposed to pro-calcific milieu, VSMCs undergo phenotypic transition characterized by the loss of contractile markers including smooth muscle 22 alpha (SM22 $\alpha$ ) and alpha smooth muscle actin ( $\alpha$-SMA), followed by the increased expression of bone-related genes, such as bone morphogenetic proteins (BMPs), runt-related transcription factor 2 (Runx2), Msx, and osteocalcin [4]. There are other origins of osteoblast-like cells in the vasculature, including pericytes, endothelial cells (ECs) and circulating progenitor cells $[5,6]$. Recent studies on exosomes as well as autophagy also suggest the existence of communication among these cells in VC formation [7, 8]. However, whether there are constant cellular interactions in the process of $\mathrm{VC}$ and the underlying signaling pathway networks are still unclear.

In the present review, we summarized the current understandings of cellular interactions in VC. We attempted to provide clinicians with in-depth insights into treating VC. Further investigations are needed to 
uncover the complicated interactions among these osteoblast-like cells and to achieve a breakthrough in the therapies for $\mathrm{VC}$-associated diseases.

\section{Osteoblast-like cells in the vasculature}

As an active cell-mediated process, $\mathrm{VC}$ has been considered as bone formation by osteoblast-like cells in situ or from circulation. These cells can spontaneously produce mineralized matrix and have been identified by isolation from vascular tissue. Notably, they are derived from a variety of origins: (i) ECs in the aortic intima, (ii) pericytes in the microvessels, (iii) calcifying vascular cells (CVCs), (iv) VSMCs in the media, (v) myofibroblasts in the adventitia, and (vi) progenitor cells [5, 9] (Fig. 1).

\section{Endothelial cells}

Endothelial-mesenchymal transition (EndMT) is a process by which ECs transit into mesenchymal stem cells and gain multipotency, prior to differentiating into various cells lineages [10]. Recent studies indicate EndMT as a key mechanism for aortic and valvular ECs to undergo osteo-/chondrogenesis $[11,12]$. Usage of cinacalcet was shown to significantly abolish the up-regulation of mesenchymal markers (fibroblast-specific protein 1 and $\alpha$-SMA) and the down-regulation of the endothelial marker (CD31), resulting in attenuation of $\mathrm{VC}$ in uremic aorta samples [13]. When stimulated with transforming growth factor- $\beta$ (TGF- $\beta$ ), valvular ECs underwent EndMT, followed by an increase of osteocalcin, osteopontin mRNA and Runx2. Addition of valvular interstitial cells inhibited this process, indicating the importance of the interactions between valvular ECs and interstitial cells in valve calcification [14].

\section{Pericytes}

Pericytes are perivascular cells found in abundance around ECs and share a similar support function as VSMCs. As an integral part of the microvasculature, pericytes regulate numerous functions, including vessel growth, permeability, and contractility $[15,16]$. When exposed to inflammatory stimuli, pericytes turn into mesenchymal progenitors and develop into osteoblasts and chondrocytes [17]. In vivo, pericytes implanted in athymic mice were shown to develop into a variety of skeletal tissues, including bone, mineralized cartilage, and nonmineralized cartilage-like regions [18]. In long-term culture, pericytes also produce large nodules containing type I collagen, osteopontin, matrix Gla protein (MGP), and osteocalcin [19].

Clinical prescription with glucocorticoids (cortisol, corticosterone, dexamethasone) for a long period are closely associated with osteoporosis; however, these compounds have been shown to induce an osteo-/chondrogenic phenotypic switch in pericytes [20]. Elevated endogenous glucocorticoids were shown to act through mineralocorticoid receptor and facilitate phosphateinduced VSMC calcification [21]. Administration of dexamethasone reduced the expression of MGP, osteopontin and $\mathrm{VC}$-associated factor mRNA on the pericytes, resulting in increased ALP activity and calcium deposition $[20]$.



Fig. 1 Schematic representation of osteoblast-like cells derived from different origins mediating VC. There are various origins of osteoblast-like cells in the vasculature, including ECs, pericytes, VSMCs, CVCs, myofibroblasts, and circulating progenitor cells. They collaboratively participate in the initiation and development of VC in the media or intima. CVCs calcifying vascular cells, ECs endothelial cells, MSC mesenchymal stem cell, VC vascular calcification, VSMCs vascular smooth muscle cells 


\section{Medial cells}

The ability to undergo reversible differentiation is characteristic of the VSMC phenotype; these cells are in their differentiated and contractile form at baseline but respond to various stimuli by entering a proliferative, synthetic state. Several stimuli induce VSMCs to undergo osteogenic differentiation, including oxidative stress, inflammation or changes in pyrophosphate levels [22-24].

Growing evidence have identified the existence of a subpopulation of VSMCs and CVCs, which spontaneously form nodules and calcify when maintained in long-term culture $[25,26]$. These nodules share many properties with bone, including increased alkaline phosphate (ALP) activity, osteocalcin, and osteopontin expression [27]. These cells also have the potential for multiple mesenchymal lineages, including osteoblasts, and represent $20-30 \%$ of the total VSMC population [25]. Several anti-hypertensive (spironolactone) or anti-diabetic drugs (exenatide) have been shown to exert additional effects on inhibiting CVCs calcification in vitro $[28,29]$.

\section{Adventitial cells}

On the external side of the vascular wall, aortic adventitial myofibroblasts have been implicated in osteogenic programs in diabetic mice fed with high-fat diet [30]. A recent study identified $\mathrm{Gli1}^{+}$mesenchymal stem cell (MSC)-like cells residing in the arterial adventitia as the progenitors of VSMCs, which contributed to neointima formation and arterial repair. However, genetic ablation of $\mathrm{Gli}^{+}{ }^{+}$cells before injury abolishes VC [31].

\section{Progenitor cells}

In addition to the cells surrounding the vasculature, there are several types of circulating progenitor cells participating in VC formation [32, 33]. Patients with elevated glycated hemoglobin had a higher percentage of circulating endothelial progenitor cells, which potentially mediated diabetic vasculopathy especially $\mathrm{VC}$ [34]. Similarly, in women with postmenopausal osteoporosis, it was demonstrated that the number of circulating osteoprogenitor cells was significantly associated with the presence and severity of abdominal aortic calcium independent of other potential confounders [35]. Bone marrow-derived and vessel-resident progenitor cells had the potential to shift into osteoblastic or osteoclastic cells in the artery wall [36]. Interestingly, treated with the peroxisome proliferator activated receptor $\gamma$ agonist limited these cells to become osteoclasts instead of osteoblasts, offering a new therapeutic target for reversing $\mathrm{VC}$ [36].

\section{Signaling pathways among osteoblast-like cells}

Although there are multiple types of osteoblast-like cells, they communicate with each other through different signaling pathways, in turn form a highly efficient network in the development of VC (Fig. 2). Thus, intervening these pathways, especially the core factors in the network, may inhibit the progression of VC. In the following sections, we will discuss a list of regulatory signaling pathways known to be involved in $\mathrm{VC}$ among the osteoblast-like cells.

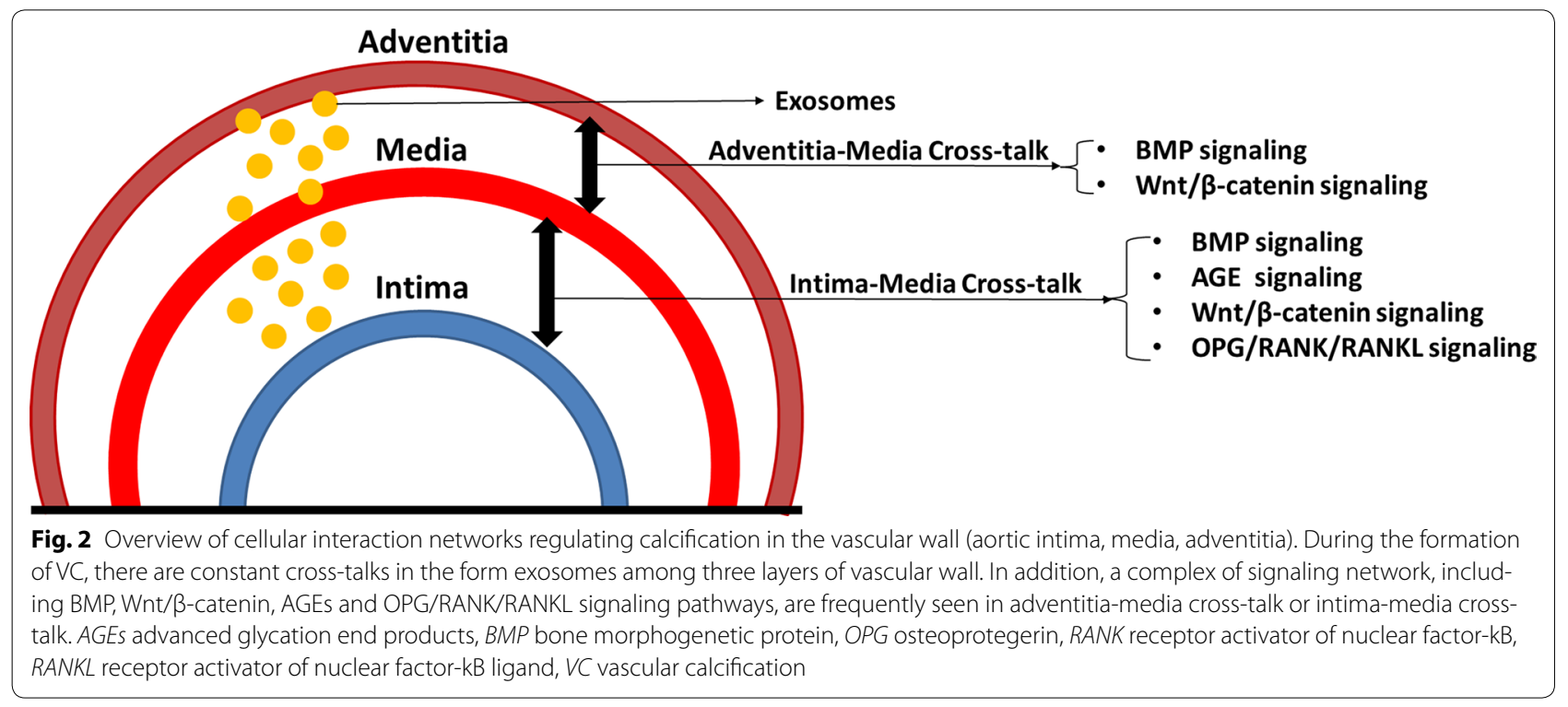




\section{BMP signaling pathways}

The BMPs constitute a sub-group of the TGF- $\beta$ superfamily growth factors, which is essential in vascular disease. Abnormal interactions between ECs and pericytes are implicated in a number of human pathological conditions, including tumor angiogenesis, diabetic microangiopathy, and ectopic tissue calcification. Endothelium-derived TGF- $\beta$ signaling is important for pericyte differentiation [37]. Similarly, in a low-density lipoprotein receptor-deficient mouse model, it was shown that MSCs in the circulation were recruited to the diseased vasculature and contributed to the development of VC. However, addition of neutralizing antibody or the inhibitor of TGF- $\beta$ Receptor I kinase blocked this effect, suggesting that it was TGF- $\beta$-mediated [38]. Moreover, several BMPs activation has been associated with atherosclerosis, diabetic vasculopathy, and chronic kidney disease, all of which were known to accelerate the process of VC [39].

The BMPs have cell-specific actions and their effects on $\mathrm{VC}$ are dependent on the location and the type of cells they are expressed on. Aortic adventitial myofibroblasts from SM22-Cre mice secret BMP2 and participate in a pro-calcific program under high plasma glucose concentration [30]. In vascular media, BMP2 acted through the type III sodium-dependent phosphate cotransporter, Pit1, down-regulated the microRNA-30b and 30c, resulting in an increased expression of Runx2, calcium deposition, and mineralization. The inhibition of phosphate uptake or transfection with microRNA-30b-c could abrogate these effects [40]. In addition, BMP2 elevated aggrecan message and type II collagen mRNA, which further induced osteo-/chondrogenic phenotypic switch of pericytes [41]. In diabetic mice, it was shown that BMP2 induced Msx and lipoprotein receptor-related protein (LRP) expression, and exerted pro-calcific effects [42]. Moreover, in the aortic intima, BMP4 and BMP7 had similar functions in mediating inflammation as well as EndMTs, which attenuated VC in CKD $[10,43]$.

Taken together, BMPs may derive from three layers of vascular wall, bind to the BMP receptors on ECs, pericytes or VSMCs, in turn accelerate medial or intimal calcification.

\section{OPG/RANK/RANKL signaling pathway}

Recent discovery of OPG/receptor activator of nuclear factor-kB (RANK)/RANK ligand (RANKL) system builds a physiopathological link between bone loss and VC [44]. In mice, OPG knockdown presented severe osteoporosis and VC, but OPG overexpression reduced osteoclast differentiation from precursor cells and increased bone mass $[45,46]$. It is clear that RANKL binds to its physiologic receptor, RANK, in turn promotes osteoclast differentiation. However, OPG interferes with the interaction between RANK and RANKL and inhibits this process [47]. It seemed inconsistent that serum OPG levels were increased in the presence of $\mathrm{VC}$ [48], but this may be a reflection of noxious OPG activity or a compensatory mechanism. Growing evidence have demonstrated the vascular OPG/RANK/RANKL axis plays an important role in the cellular interactions under pro-calcific setting [44].

From a total of 73 carotid plaques (49 asymptomatic and 24 symptomatic) data, Davaine et al. showed that higher presence of OPG and pericytes was significantly associated with carotid plaques stability [49]. In vitro study, further demonstrated that human vascular pericytes secreted considerable amounts of OPG and underwent osteoblastic differentiation. Pericytes also inhibited the osteoblastic differentiation of CD14+ through the secretion of OPG, suggesting the complex functions of OPG in VC [49]. Interestingly, it was demonstrated that RANKL increased BMP2 release from human aortic ECs (HAECs). The exposure of human aortic SMCs (HASMCs) to RANKL-treated HAEC-conditioned media induced osteoblastic behavior in HASMCs [50]. This phenomenon indicated the importance of HAECHASMC signaling to $\mathrm{VC}$ in the context of OPG and RANKL.

\section{Advanced glycation end products (AGEs) signaling pathways}

Derived from non-enzymatic modification of proteins by glucose, AGEs play an important role in the pathogenesis of numerous diseases, including diabetic complications, atherosclerosis and aging [51]. AGEs formed at an accelerated rate especially under diabetes. AGEs may accumulate in heart and blood vessels, leading to accelerated plaque formation and increased cardiac fibrosis [52].

In the bovine pericyte culture, AGEs and the receptor for AGEs (RAGEs) were shown to enhance the number of calcified nodules, accompanied by an increase of ALP and OPN mRNAs [53]. Further studies demonstrated that AGEs enhanced VSMC calcification partly through a RAGEs/oxidative stress pathway [54]. Transduced HASMCs with adenovirus expressing RAGEs induced ALP, calcium deposition and osteogenic differentiation defined by an increase of Msx and BMP2 expression [55]. However, others' and our findings indicated that administration of different antioxidants like apocynin could significantly ameliorate diabetes-induced calcification [56, 57]. Importantly, the expression of $\beta$-catenin was shown to increase with the AGEs concentrations augment in AGEs-induced VSMC calcification, suggesting that there was a cross-talk between AGEs and Wnt/ $\beta$-catenin signaling pathways [58]. 
Thus, in diabetes, circulating AGEs may impair vascular intima, bind to RAGEs and mediate the crosstalk between ECs and VSMCs/pericytes, in turn participate in the formation of $\mathrm{VC}$.

\section{Wnt/ $\beta$-catenin signaling pathway}

Wnts are a large family of conserved secreted carbohydrate and lipid-modified proteins that are involved in cell differentiation, proliferation and death [59]. They bind to cell-surface receptors of the Frizzled family and LRP-5/6, resulting in nuclear $\beta$-catenin translocation and specific gene expression [60]. Many proteins related with VC are known Wnt target genes, including Runx2 and osteocalcin. In addition to this canonical pathway, there exist $\beta$-catenin-independent pathways, such as $\mathrm{Ca}^{2+} /$ protein kinase A pathway, G-protein/protein kinase C/JNK signaling pathway and Src/ERK pathway [61].

Glucose, inflammation and reactive oxygen species up-regulate BMP2/4 production by pericytes and ECs, in turn promote adventitial Msx2-Wnt signaling. Then, the enhanced Wnt production increased medial nuclear $\beta$-catenin accumulation, ALP activity, and osteogenic differentiation [62, 63]. The aberrant differentiation of pericytes contributed to the development and progression of several vascular pathologies [18]. Importantly, Kirton et al. demonstrated that canonical Wnt/ $\beta$-catenin signaling could inhibit adipogeic differentiation and enhance chondrogenic differentiation of pericytes [64]. Two vitamin D receptor agonists, calcitriol and paricalcitol have differential effects on VC, which was mediated by a distinct regulation of the BMP and Wnt/ $\beta$-catenin signaling pathways [65]. Similarly, activation of Wnt/beta-catenin signaling pathway was also shown to motivate calcium deposition via BMP-2 in pericytes, indicating that these two pathways may interact synergistically to contribute VC [66].

However, the role of non-canonical Wnts pathways in the process of $\mathrm{VC}$ is still under debate. It was shown that LRP6 promoted osteo-/chondrogenic differentiation of VSMCs via upstream stimulatory factor1- and arginine methylation-dependent relays [67]. But in calcified aortic valves, Albanese et al. found a significant correlation between Wnt5b and Wnt11 overall staining and the presence of calcification, which could be reduced by mitogenactivated protein kinase-38 $\beta$ and GSK3 $\beta$ inhibitors [68]. These contradictory results could be attributed to bidirectional functions of non-canonical Wnts pathways in different cells lineages.

Like BMP signaling pathway, Wnt/ $\beta$-catenin signaling also plays an important role in the crosstalk among aortic intima, media, adventitia.

\section{Other evidence of cellular interactions in VC}

In addition to multiple signaling pathways, there are also constant interactions in terms of 'message carriers' among osteoblast-like cells (Fig. 2). Outside disease milieu, uremic serum from patients was shown to induce calcification of cultured VSMCs, suggesting the pro-calcific messengers in CKD serum, termed as exosomes [69]. Exosomes are novel intercellular communication messengers containing biologically active proteins, lipids and RNA species. Pro-inflammatory cytokines and growth factors, as well as mineral imbalance, stimulate VSMCs to secrete thousands of exosomes. They play important roles in vascular repair, thrombosis and calcification in a paracrine or autocrine manner [70]. In response to environmental calcium stress, VSMCs can autonomously secret multiple exosomes enriched with sphingomyelin phosphodiesterase 3 and CD63, leading to increased calcification of neighboring normal VSMCs [8].

In addition, autophagy is an adaptive stress response whereby cells remove unnecessary or dysfunctional cellular components by targeting them to modified lysosomes for degradation or recycling [7]. Emerging evidence indicate that autophagy also regulates extracellular matrix homeostasis and mitigates $\mathrm{VC}$ formation [71, 72]. In the setting of hyperphosphatemia, autophagy may be an endogenous protective mechanism counteracting phosphate-induced VC. Administration of an inducer of autophagy, valproic acid, significantly decreased VC. However, pretreatment of an autophagy inhibitor, 3-methylademine, promoted matrix vesicle release with increased ALP activity [73].

Except for VSMCs, other types of vascular cells may also have the potential to secrete exosomes under procalcific conditions, and influence nearby normal cells and accelerate $\mathrm{VC}$ formation.

\section{Conclusion}

Vascular calcification is a hallmark and major risk factor for cardiovascular morbidity and mortality. In this present review, we highlight the findings that multiple osteoblast-like cells and signaling pathways are involved in the initiation and development of VC. However, direct evidence about the roles of cellular interactions in $\mathrm{VC}$ was limited and the underlying mechanisms are still not very clear. Thus, future studies are required to explore these mechanisms in detail. With more clues uncovered, comprehensive treatments targeting cellular interactive network may provide clinicians with a novel therapy for attenuating $\mathrm{VC}$ and reducing cardiovascular events. 


\section{Abbreviations}

AGEs: advanced glycation end-products; a-SMA: alpha smooth muscle actin; RAGEs: receptor for advanced glycation end products; ALP: alkaline phosphatase; BMPs: bone morphological proteins; CKD: chronic kidney disease; CVCs: calcifying vascular cells; ECs: endothelial cells; EndMT: endothelial-mesenchymal transition; HAECs: human aortic endothelial cells; HASMCs: human aortic smooth muscle cells; LRP: lipoprotein receptor-related protein; MGP. matrix Gla protein; MSC: mesenchymal stem cell; OPG: osteoprotegerin; RANK: receptor activator of nuclear factor-kB; RANKL: receptor activator of nuclear factor-KB ligand; SM22a: smooth muscle 22 alpha; TGF- $\beta$ : transforming growth factor- $\beta$; VSMCs: vascular smooth muscle cells; VC: vascular calcification.

\section{Authors' contributions}

ASAB, JWG and KZ contributed equally to this article. All the authors participated in the design of the study and drafted the manuscript. HH participated in the study coordination and helped to draft the manuscript. ASAB, JWG and $K Z$ revised the paper. All authors read and approved the final manuscript.

\section{Author details}

1 Zhongshan Medical School, Sun Yat-sen University, Guangzhou, China. ${ }^{2}$ Guangdong Provincial Key Laboratory of Malignant Tumor Epigenetics and Gene Regulation, Department of Cardiology, Sun Yat-sen Memorial Hospital, Sun Yat-sen University, 107 West Yanjiang Road, Guangzhou 510120, China. ${ }^{3}$ Laboratory of RNA and Major Diseases of Brain and Heart, Sun Yat-sen Memorial Hospital, Sun Yat-sen University, Guangzhou, China.

\section{Acknowledgements \\ Not applicable.}

\section{Competing interests}

The authors declare that they have no competing interests.

\section{Funding}

This work was supported in part by National Natural Science Foundation of China (NSFC) [81670676, 81422011, 81370837], the Natural Science Foundation of Guangdong Province [2014A030313035], Guangzhou science and technology project [2060404] and the Fundamental Research Funds for the Central Universities [2015ykzd09] to Hui Huang.

\section{Publisher's Note}

Springer Nature remains neutral with regard to jurisdictional claims in published maps and institutional affiliations.

Received: 28 December 2016 Accepted: 20 April 2017 Published online: 03 May 2017

\section{References}

1. Gao J, Zhang K, Chen J, Wang MH, Wang J, Liu P, Huang H. Roles of aldosterone in vascular calcification: an update. Eur J Pharmacol. 2016;786:186-93.

2. Zhang K, Gao J, Chen J, Liu X, Cai Q, Liu P, Huang H. MICS, an easily ignored contributor to arterial calcification in CKD patients. Am J Physio Renal Physiol. 2016:311:F663-70.

3. Vassalle C, Mazzone A. Bone loss and vascular calcification: a bi-directional interplay? Vascul Pharmacol. 2016;86:77-86.

4. Leopold JA. Vascular calcification: mechanisms of vascular smooth muscle cell calcification. Trends Cardiovasc Med. 2015;25:267-74.

5. Albiero M, Avogaro A, Fadini GP. Circulating cellular players in vascular calcification. Curr Pharm Des. 2014;20:5889-96.

6. Johnson RC, Leopold JA, Loscalzo J. Vascular calcification: pathobiological mechanisms and clinical implications. Circ Res. 2006;99:1044-59.

7. Shanahan CM. Autophagy and matrix vesicles: new partners in vascular calcification. Kidney Int. 2013;83:984-6.

8. Kapustin AN, Chatrou ML, Drozdov I, Zheng Y, Davidson SM, Soong D, Furmanik M, Sanchis P, De Rosales RT, Alvarez-Hernandez D, Shroff R, Yin X, Muller K, Skepper JN, Mayr M, Reutelingsperger CP, Chester A, Bertazzo S, Schurgers LJ, Shanahan CM. Vascular smooth muscle cell calcification is mediated by regulated exosome secretion. Circ Res. 2015;116:1312-23.

9. Demer LL, Tintut Y. Vascular calcification: pathobiology of a multifaceted disease. Circulation. 2008;117:2938-48.

10. Yao J, Guihard PJ, Blazquez-Medela AM, Guo Y, Moon JH, Jumabay M, Boström KI, Yao Y. Serine protease activation essential for endothelialmesenchymal transition in vascular calcification novelty and significance. Circ Res. 2015;117:758-69.

11. Yao Y, Jumabay M, Ly A, Radparvar M, Cubberly MR, Bostrom KI. A role for the endothelium in vascular calcification. Circ Res. 2013;113:495-504.

12. Boström KI, Yao J, Guihard PJ, Blazquez-Medela AM, Yao Y. Endothelialmesenchymal transition in atherosclerotic lesion calcification. Atherosclerosis. 2016;253:124-7.

13. Wu M, Tang RN, Liu H, Pan MM, Liu BC. Cinacalcet ameliorates aortic calcification in uremic rats via suppression of endothelial-to-mesenchymal transition. Acta Pharmacol Sin. 2016:37:1423-31.

14. Hjortnaes J, Shapero K, Goettsch C, Hutcheson JD, Keegan J, Kluin J, Mayer JE, Bischoff J, Aikawa E. Valvular interstitial cells suppress calcification of valvular endothelial cells. Atherosclerosis. 2015;242:251-60.

15. Murray IR, Baily JE, Chen WC, Dar A, Gonzalez ZN, Jensen AR, Petrigliano FA, Deb A, Henderson NC. Skeletal and cardiac muscle pericytes: functions and therapeutic potential. Pharmacol Ther. 2017:171:65-74.

16. Canfield AE, Doherty MJ, Wood AC, Farrington C, Ashton B, Begum N, Harvey B, Poole A, Grant ME, Boot-Handford RP. Role of pericytes in vascular calcification: a review. Z Kardiol. 2000;89(Suppl 2):20-7.

17. Leszczynska A, O'Doherty A, Farrell E, Pindjakova J, O'Brien FJ, O'Brien T, Barry F, Murphy M. Differentiation of vascular stem cells contributes to ectopic calcification of atherosclerotic plaque. Stem Cells. 2016:34:913-23.

18. Farrington-Rock C, Crofts NJ, Doherty MJ, Ashton BA, Griffin-Jones C, Canfield AE. Chondrogenic and adipogenic potential of microvascular pericytes. Circulation. 2004;110:2226-32.

19. Doherty MJ, Ashton BA, Walsh S, Beresford JN, Grant ME, Canfield AE. Vascular pericytes express osteogenic potential in vitro and in vivo. J Bone Miner Res. 1998;13:828-38.

20. Kirton JP, Wilkinson FL, Canfield AE, Alexander MY. Dexamethasone downregulates calcification-inhibitor molecules and accelerates osteogenic differentiation of vascular pericytes: implications for vascular calcification. Circ Res. 2006;98:1264-72.

21. Zhu D, Rashdan NA, Chapman KE, Hadoke PW, MacRae VE. A novel role for the mineralocorticoid receptor in glucocorticoid driven vascular calcification. Vasc Pharmacol. 2016:86:87-93.

22. Cui L, Li Z, Chang X, Cong G, Hao L. Quercetin attenuates vascular calcification by inhibiting oxidative stress and mitochondrial fission. Vasc Pharmacol. 2017;88:21-9.

23. O'Rourke C, Shelton G, Hutcheson JD, Burke MF, Martyn T, Thayer TE, Shakartzi HR, Buswell MD, Tainsh RE, Yu B, Bagchi A, Rhee DK, Wu C, Derwall M, Buys ES, Yu PB, Bloch KD, Aikawa E, Bloch DB, Malhotra R. Calcification of vascular smooth muscle cells and imaging of aortic calcification and inflammation. J Vis Exp. 2016. doi:10.3791/54017.

24. Li X, Yang HY, Giachelli CM. Role of the sodium-dependent phosphate cotransporter, Pit-1, in vascular smooth muscle cell calcification. Circ Res. 2006:98:905-12.

25. Parhami F, Bostrom K, Watson K, Demer LL. Role of molecular regulation in vascular calcification. J Atheroscler Thromb. 1996:3:90-4.

26. Ting TC, Miyazaki-Anzai S, Masuda M, Levi M, Demer LL, Tintut Y, Miyazaki M. Increased lipogenesis and stearate accelerate vascular calcification in calcifying vascular cells. J Biol Chem. 2011;286:23938-49.

27. Steitz SA, Speer MY, Curinga G, Yang HY, Haynes P, Aebersold R, Schinke T, Karsenty G, Giachelli CM. Smooth muscle cell phenotypic transition associated With calcification: upregulation of Cbfa1 and downregulation of smooth muscle lineage markers. Circ Res. 2001:89:1147-54.

28. Zhan JK, Tan P, Wang YJ, Wang Y, He JY, Tang ZY, Huang W, Liu YS. Exenatide can inhibit calcification of human VSMCs through the NF-kappaB/ RANKL signaling pathway. Cardiovasc Diabetol. 2014;13:153.

29. Jaffe IZ, Tintut Y, Newfell BG, Demer LL, Mendelsohn ME. Mineralocorticoid receptor activation promotes vascular cell calcification. Arterioscler Thromb Vasc Biol. 2007;27:799-805.

30. Cheng SL, Behrmann A, Shao JS, Ramachandran B, Krchma K, Bello Arredondo Y, Kovacs A, Mead M, Maxson R, Towler DA. Targeted reduction of vascular Msx1 and Msx2 mitigates arteriosclerotic calcification and 
aortic stiffness in LDLR-deficient mice fed diabetogenic diets. Diabetes. 2014;63:4326-37.

31. Kramann R, Goettsch C, Wongboonsin J, Iwata H, Schneider Rebekka K, Kuppe C, Kaesler N, Chang-Panesso M, Machado Flavia G, Gratwohl S, Madhurima K, Hutcheson Joshua D, Jain S, Aikawa E, Humphreys Benjamin D. Adventitial MSC-like cells are progenitors of vascular smooth muscle cells and drive vascular calcification in chronic kidney disease. Cell Stem Cell. 2016;19:628-42.

32. Vasuri F, Fittipaldi S, Pasquinelli G. Arterial calcification: finger-pointing at resident and circulating stem cells. World J Stem Cells. 2014;6(5):540-51.

33. Yang SW, Hennessy RR, Khosla S, Lennon R, Loeffler D, Sun T, Liu Z, Park KH, Wang FL, Lerman LO, Lerman A. Circulating osteogenic endothelial progenitor cell counts: new biomarker for the severity of coronary artery disease. Int J Cardiol. 2017;227:833-9.

34. Flammer AJ, GossI M, Li J, Matsuo Y, Reriani M, Loeffler D, Simari RD, Lerman LO, Khosla S, Lerman A. Patients with an HbA1c in the prediabetic and diabetic range have higher numbers of circulating cells with osteogenic and endothelial progenitor cell markers. J Clin Endocrinol Metab. 2012;97:4761-8.

35. Pirro M, Manfredelli MR, Schillaci G, Helou RS, Bagaglia F, Melis F, Scalera GB, Scarponi AM, Gentile E, Mannarino E. Association between circulating osteoblast progenitor cells and aortic calcifications in women with postmenopausal osteoporosis. Nutr Metab Cardiovasc Dis. 2013;23:466-72.

36. Cho HJ, Cho HJ, Lee HJ, Song MK, Seo JY, Bae YH, Kim JY, Lee HY, Lee W, Koo BK, Oh BH, Park YB, Kim HS. Vascular calcifying progenitor cells possess bidirectional differentiation potentials. PLoS Biol. 2013;11:e1001534.

37. Armulik A, Abramsson A, Betsholtz C. Endothelial/pericyte interactions. Circ Res. 2005;97:512-23.

38. Wang W, Li C, Pang L, Shi C, Guo F, Chen A, Cao X, Wan M. Mesenchymal stem cells recruited by active TGFbeta contribute to osteogenic vascular calcification. Stem Cells Dev. 2014;23:1392-404.

39. Yao Y, Bennett BJ, Wang X, Rosenfeld ME, Giachelli C, Lusis AJ, Bostrom Kl. Inhibition of bone morphogenetic proteins protects against atherosclerosis and vascular calcification. Circ Res. 2010;107:485-94.

40. Li X, Yang HY, Giachelli CM. BMP-2 promotes phosphate uptake, phenotypic modulation, and calcification of human vascular smooth muscle cells. Atherosclerosis. 2008;199:271-7.

41. Diefenderfer DL, Brighton CT. Microvascular pericytes express aggrecan message which is regulated by BMP-2. Biochem Biophys Res Commun. 2000;269:172-8.

42. Shao JS, Aly ZA, Lai CF, Cheng SL, Cai J, Huang E, Behrmann A, Towler DA. Vascular BMP-Msx2-Wnt signaling and oxidative stress in arterial calcification. Ann N Y Acad Sci. 2007;1117:40-50.

43. Freedman BI, Bowden DW, Ziegler JT, Langefeld CD, Lehtinen AB, Rudock ME, Lenchik L, Hruska KA, Register TC, Carr JJ. Bone morphogenetic protein 7 (BMP7) gene polymorphisms are associated with inverse relationships between vascular calcification and BMD: the Diabetes Heart Study. J Bone Miner Res. 2009;24:1719-27.

44. D'Amelio P, Isaia G, Isaia GC. The osteoprotegerin/RANK/RANKL system: a bone key to vascular disease. J Endocrinol Invest. 2009;32:6-9.

45. Min H, Morony S, Sarosi I, Dunstan CR, Capparelli C, Scully S, Van G, Kaufman S, Kostenuik PJ, Lacey DL, Boyle WJ, Simonet WS. Osteoprotegerin reverses osteoporosis by inhibiting endosteal osteoclasts and prevents vascular calcification by blocking a process resembling osteoclastogenesis. J Exp Med. 2000;192:463-74.

46. Simonet WS, Lacey DL, Dunstan CR, Kelley M, Chang MS, Luthy R, Nguyen HQ, Wooden S, Bennett L, Boone T, Shimamoto G, DeRose M, Elliott R, Colombero A, Tan HL, Trail G, Sullivan J, Davy E, Bucay N, Renshaw-Gegg L, Hughes TM, Hill D, Pattison W, Campbell P, Sander S, Van G, Tarpley J, Derby P, Lee R, Boyle WJ. Osteoprotegerin: a novel secreted protein involved in the regulation of bone density. Cell. 1997;89:309-19.

47. Evrard S, Delanaye P, Kamel S, Cristol JP, Cavalier E, calcifications SSjwgov. Vascular calcification: from pathophysiology to biomarkers. Clin Chim Acta. 2015;438:401-14.

48. Morena M, Dupuy AM, Jaussent I, Vernhet H, Gahide G, Klouche K, Bargnoux AS, Delcourt C, Canaud B, Cristol JP. A cut-off value of plasma osteoprotegerin level may predict the presence of coronary artery calcifications in chronic kidney disease patients. Nephrol Dial Transplant. 2009;24:3389-97.

49. Davaine JM, Quillard T, Brion R, Laperine O, Guyomarch B, Merlini T, Chatelais M, Guilbaud F, Brennan MA, Charrier C, Heymann D, Goueffic
Y, Heymann MF. Osteoprotegerin, pericytes and bone-like vascular calcification are associated with carotid plaque stability. PLOS ONE. 2014;9:e107642.

50. Davenport C, Harper E, Forde H, Rochfort KD, Murphy RP, Smith D, Cummins PM. RANKL promotes osteoblastic activity in vascular smooth muscle cells by upregulating endothelial BMP-2 release. Int J Biochem Cell Biol. 2016;77:171-80.

51. Vlassara H. Advanced glycation end-products and atherosclerosis. Ann Med. 1996;28:419-26.

52. Towler DA. Vascular calcification: it's all the RAGE! Arterioscler Thromb Vasc Biol. 2011;31:237-9.

53. Yamagishi S, Fujimori H, Yonekura H, Tanaka N, Yamamoto H. Advanced glycation endproducts accelerate calcification in microvascular pericytes. Biochem Biophys Res Commun. 1999;258:353-7.

54. Wei Q, Ren X, Jiang Y, Jin H, Liu N, Li J. Advanced glycation end products accelerate rat vascular calcification through RAGE oxidative stress. BMC Cardiovasc Disord. 2013;13:13.

55. Suga T, Iso T, Shimizu T, Tanaka T, Yamagishi S, Takeuchi M, Imaizumi T, Kurabayashi M. Activation of receptor for advanced glycation end products induces osteogenic differentiation of vascular smooth muscle cells. J Atheroscler Thromb. 2011;18:670-83.

56. Brodeur MR, Bouvet C, Bouchard S, Moreau S, Leblond J, Deblois D, Moreau P. Reduction of advanced-glycation end products levels and inhibition of RAGE signaling decreases rat vascular calcification induced by diabetes. PLoS ONE. 2014;9:e85922.

57. Feng W, Zhang K, Liu Y, Chen J, Cai Q, Zhang Y, Wang M, Wang J, Huang H. Apocynin attenuates angiotensin II-induced vascular smooth muscle cells osteogenic switching via suppressing extracellular signal-regulated kinase 1/2. Oncotarget. 2016;7:83588-600.

58. He HQ, Liu Y, Zeng H, Sun XL, Zhang L, Zhang XL, Liao WJ, Zhou XY, He YZ. Advanced glycation endproducts regulate smooth muscle cells calcification in cultured HSMCs. Int J Clin Exp Pathol. 2015;8:12260-7.

59. Hoppler S, Kavanagh CL. Wnt signalling: variety at the core. J Cell Sci. 2007;120:385-93.

60. Johnson ML, Rajamannan N. Diseases of Wnt signaling. Rev Endocr Metab Disord. 2006;7:41-9.

61. van Amerongen R, Mikels A, Nusse R. Alternative wnt signaling is initiated by distinct receptors. Sci Signal. 2008;1:r9.

62. Shao JS, Cheng SL, Pingsterhaus JM, Charlton-Kachigian N, Loewy AP, Towler DA. Msx2 promotes cardiovascular calcification by activating paracrine Wnt signals. J Clin Invest. 2005;115:1210-20.

63. Shao JS. Molecular mechanisms of vascular calcification: lessons learned from the aorta. Arterioscler Thromb Vasc Biol. 2006;26:1423-30.

64. Kirton JP, Crofts NJ, George SJ, Brennan K, Canfield AE. Wnt/beta-catenin signaling stimulates chondrogenic and inhibits adipogenic differentiation of pericytes: potential relevance to vascular disease? Circ Res. 2007;101:581-9.

65. Martinez-Moreno JM, Munoz-Castaneda JR, Herencia C, Oca AM, Estepa JC, Canalejo R, Rodriguez-Ortiz ME, Perez-Martinez P, Aguilera-Tejero E, Canalejo A, Rodriguez M, Almaden Y. In vascular smooth muscle cells paricalcitol prevents phosphate-induced Wnt/beta-catenin activation. Am J Physiol Renal Physiol. 2012;303:F1136-44.

66. Rong S, Zhao X, Jin X, Zhang Z, Chen L, Zhu Y, Yuan W. Vascular calcification in chronic kidney disease is induced by bone morphogenetic protein-2 via a mechanism involving the Wnt/beta-catenin pathway. Cell Physiol Biochem. 2014;34:2049-60.

67. Cheng S-L, Ramachandran B, Behrmann A, Shao J-S, Mead M, Smith C, Krchma K, Bello Arredondo Y, Kovacs A, Kapoor K, Brill LM, Perera R, Williams BO, Towler DA. Vascular smooth muscle LRP6 limits arteriosclerotic calcification in diabetic LDLR -/ - mice by restraining noncanonical Wnt signals. Circ Res. 2015;117:142-56.

68. Albanese I, Yu B, Al-Kindi H, Barratt B, Ott L, Al-Refai M, de Varennes B, Shum-Tim D, Cerruti M, Gourgas O, Rheaume E, Tardif JC, Schwertani A. Role of noncanonical Wnts signaling pathway in human aortic valve calcification. Arterioscler Thromb Vasc Biol. 2017. doi:10.1161/ ATVBAHA.116.308394.

69. Patidar A, Singh DK, Winocour P, Farrington K, Baydoun AR. Human uraemic serum displays calcific potential in vitro that increases with advancing chronic kidney disease. Clin Sci (Lond). 2013;125:237-45. 
70. Kapustin AN, Shanahan CM. Emerging roles for vascular smooth muscle cell exosomes in calcification and coagulation. J Physiol. 2016;594:2905-14.

71. Ciceri P, Elli F, Braidotti P, Falleni M, Tosi D, Bulfamante G, Block GA, Cozzolino M. Iron citrate reduces high phosphate-induced vascular calcification by inhibiting apoptosis. Atherosclerosis. 2016;254:93-101.
72. Xu M, Liu L, Song C, Chen W, Gui S. Ghrelin improves vascular autophagy in rats with vascular calcification. Life Sci. 2016. doi:10.1016/j. Ifs.2016.11.025

73. Dai XY, Zhao MM, Cai Y, Guan QC, Zhao Y, Guan Y, Kong W, Zhu WG, Xu MJ, Wang X. Phosphate-induced autophagy counteracts vascular calcification by reducing matrix vesicle release. Kidney Int. 2013;83:1042-51.

\section{Submit your next manuscript to BioMed Central and we will help you at every step:}

- We accept pre-submission inquiries

- Our selector tool helps you to find the most relevant journal

- We provide round the clock customer support

- Convenient online submission

- Thorough peer review

- Inclusion in PubMed and all major indexing services

- Maximum visibility for your research

Submit your manuscript at www.biomedcentral.com/submit 